\title{
WS017 CANDY BOX SEM
}

〜最新 SEM の理論と応用〜

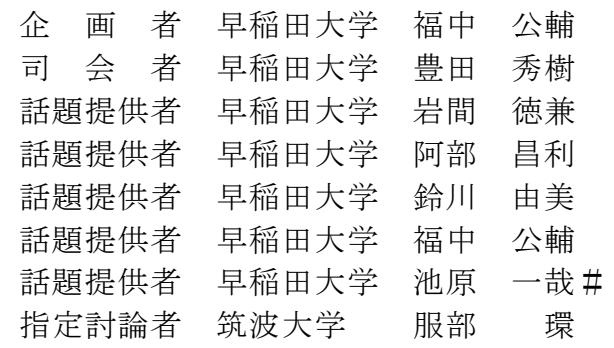

\section{概 要}

構造方程式モデリング (SEM) は数理的に非常に柔軟であり、かつ応用可能性に優れた統計解析手法である。 この手法は高度に理論的ではあるが、パス図を描画して直感的に結果を解釈できるため、人文社会科学系の 研究者が利用し、有益な情報を得ている。

しかし、SEMの理論は決して完成されたものではなく、現在も日進月歩の勢いで発展を続けている。だが、 多くの心理学者にとっては自身の研究で忙しく、SEM の最新の動向にまで手が回らないというのが現状であ ろう。また、SEM の論文は統計学を専門としていない者にとっては読みにくいという側面もある。

そこで本ワークショップでは 2000 年以降に発表された最新の SEM 理論の中で、心理学者にとって役に立つ と思われる手法を取り上げ、わかりやすく紹介する。また理論だけでなく、実際のデータを用い、ソフトウ ェアの使い方、分析の仕方、結果の解釈の仕方など、応用方法も合わせて紹介する。 